巻 頭 随 想

\title{
30 年目に脚光を浴びた酵素
}

(株)林原総合研究所取締役副社長

过阪 好夫

今から 30 余年前, 私は “くろかび”の生産する $\alpha$-グルコシダーゼを結晶として単離し, その酵素がマルトースやマルトトリオースの $\alpha-1.4$ グルコシド結合を, 転移作用によって $\alpha-1.6$ グルコシド結合を持つ，イソマルトースやイソマルトトリオースに変換することを明ら かにした。

その当時私は，その数年前に私自身でその作用機作を明らかにしたグルコアミラーゼを使っ て, 酵素法によるブドウ糖の製造研究を成功させようと必死になっていた。この研究の成否 は, 澱粉を $98 \%$ 以上ブドウ糖に分解する酵素剤の開発にかかっていた。そのため多種類の微 生物の澱粉分解系を調べ，ほとんどすべての “かび”が大なり小なりグルコアミラーゼを作る

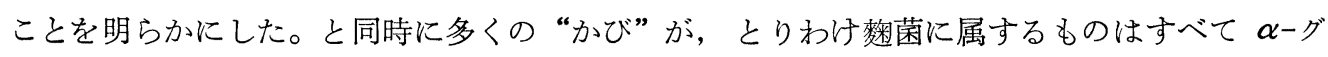
ルニシダーゼを生成することも分かった。その時, 調べた“かび”の中では“くものすかび”

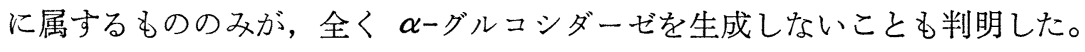

このため “くものすかび”の場合, 培養汇液そのものを用いても澱粉から $98 \%$ 以上のブド ウ糖が生成するのに対し “くろかび”の培養液では共存する $\alpha$-グルコシダーゼの作用によっ て生成する, 前述の $\alpha-1.6$ オリゴ糖にグルコアミラーゼが作用しないために, グルコースの 収率は $92 \%$ 以下に止るのである。“くものすかび”と“くろかび”の純粋なグルコアミラーゼ 標品の性質を比較すると，耐熱性や耐酸性の面で “くろかび”の酵素の方がはるかに優れてい

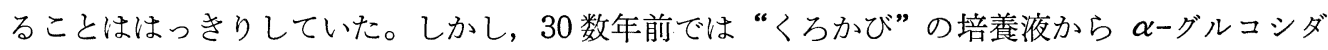
一ゼだけを撰択的に除去することは，技術的に至難のことであった。このため，私は初期のブ ドウ糖製造には“くものすかび”の酵素剤を使用することを決断したのである。

このように $\alpha$-グルコシダーゼの存在はブドウ糖工業においては最大の障害であったのであ る。ただ私がこの酵素を純化し，その性質の詳細を調べたのは，“かび”の澱粉分解に関与す るすべての酵素系を明らかにしようといら一種の使命感のしからしむる所であった。

それから 30 年経った現在, 小糖類のある物は人間の健康に何らかの効果を持つことが知ら れるようになり，一時機能性オリゴ糖といら言葉がマスコミを賑わした。現在この種の糖は 20 種類を超えていると思われるが, そのほとんどのものが庶糖, 麦芽糖, 乳糖, 水飴などを原料 として, 特殊な転移酵素によって作られている。これらの詳細を紹介する余裕はないが，その 機能を大別すると，1）ムシ歯にかかり難いもの，2）大腸のミクロフローラーの中で，いわゆ る善玉菌と言われるビフィドバクテリウムなどの成育を促進し, 整腸作用に寄与するもの,

3）以上の 2 つの機能を併世持つものである。ところで, この機能性オリゴ糖の中にイソマル トオリゴ糖と呼ばれるものがあり, 前述の 3 番目の機能を示すことから, かなりの注目を浴 び, その生産量も順調に伸びている。この糖はその名の示す如く, イソマルトース, イソマル トトリオース，パンノースなど，かつてブドウ糖の収率を下げる原因とみなされたものが主成

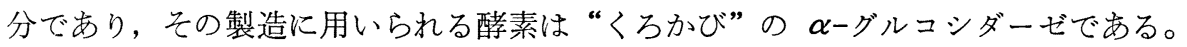

30数年前, 邪魔物以外の何物でも無かった酵素が, 漸く日の目を見るようになった。そして この酵素を憎みながらその研究を行った私自身, 一種の感慨を憶えるのである。 